ElementerIs: Jurnal Ilmiah Pendidikan Dasar Islam

Volume 1 Nomor 2 November 2019

e-ISSN: $2655-6324$

\title{
STRATEGI PENGELOLAAN KELAS DALAM MENCIPTAKAN SUASANA BELAJAR YANG KONDUSIF DI SD/MI
}

\author{
Abd. Gafur ${ }^{1}$, Fita Mustafida ${ }^{2}$ \\ UIN Maulana Malik Ibrahim ${ }^{1}$, Universitas Islam Malang² \\ e-mail: 1gafur@pgmi.uin-malang.ac.id 2fita.mustafida@unisma.ac.id
}

Diterima: 16 Desember 2019 I Direvisi: 27 Desember 2019 | Disetujui: 30 Desember 2019 (C) 2019 Pendidikan Guru Madrasah Ibtidaiyah Fakultas Agama Islam Universitas Islam Malang

\begin{abstract}
Every teacher actually wants success in teaching in class. On the other hand, the teacher is also faced with a variety of classroom situations and conditions that may not be as expected. This gap often becomes a barrier for teachers in optimizing learning activities. Therefore, to avoid various problems that arise in the classroom, teacher skills are needed in implementing conducive classroom management strategies. Conducive classes need to be created to provide learning services to students. Without conducive classes the teacher will have difficulty conditioning the learning. Like busy students, lack of enthusiasm, children bother friends and also physical problems, such as dirty, cramped, smelly and disorganized classes. This emphasizes that the teacher as class manager does not just prepare learning materials, deliver learning, and evaluate the progress of student learning outcomes, but also relates to the task of fostering and creating, maintaining and improving class systems or organizations so that students feel comfortable and comfortable in the classroom. This is because the classroom environment influences the ability of students to focus and absorb information.
\end{abstract}

Keyword: strategy, classroom management, conducive.

\begin{abstract}
Abstrak
Setiap guru sejatinya mengiginkan sukses dalam mengajar di kelas. Di lain sisi, guru juga dihadapkan dengan berbagai situasi dan kondisi kelas yang mungkin saja tidak sesuai dengan yang diharapkan. Kesenjangan ini seringkali menjadi hambatan guru dalam mengoptimalkan kegiatan pembelajaran. Oleh sebab itu, untuk menghindari berbagai permasalah yang muncul di kelas, diperlukan keterampilan guru dalam menerapkan strategi mengelola kelas yang kondusif. Kelas kondusif perlu diciptakan untuk memberikan pelayanan pembelajaran kepada siswa. Tanpa kelas kondusifguru akan kesulitan mengkondisikan pembelajaran. Seperti siswa ramai, kurang bersemangat, anak mengganggu teman dan juga masalah-masalah fisik, seperti kelas kotor, sempit, bau dan tidak teratur. Hal ini mempertegas bahwa guru sebagai pengelola kelas tidak sekedar menyiapkan materi pembelajaran, menyampaikan
\end{abstract}

This work is licensed under Creative Commons Attribution Non Commercial 4.0 International License Available online on: http://riset.unisma.ac.id/index.php/je 
Abd. Gafur, Fita Mustafida

pembelajaran, dan mengevaluasi perkembangan hasil belajar siswa saja, tetapi juga berkaitan dengan tugas membina dan menciptakan, memelihara serta memperbaiki sistem atau organisasi kelas sehingga peserta didik betah dan nyaman di dalam kelas. Hal ini dikarenakan lingkungan kelas berpengaruh pada kemampuan peserta didik untuk berfokus dan menyerap informasi.

Kata kunci: strategi, pengelolaan kelas, kondusif.

\section{Pendahuluan}

Suasana pembelajaran yang menggairahkan merupakan salah satu indikator keberhasilan pengelolaan kelas yang diterapkan guru. Banyak studi mengangkat kasus yang berkaitan dengan kesulitan guru dalam mengelola kelas. Hal inilah yang menyebabkan motivasi belajar turun dan siswa kurang tertarik mengikuti pembelajaran di kelas. Penelitian (Arends, 2008) menemukan bahwa pengelolaan kelas merupakan tantangan paling sulit yang dihadapi guru dalam menciptakan lingkungan belajar yang optimal. Hal tersebut juga banyak diteliti oleh para akademisi terutama tentang dampak pengelolaan kelas terhadap semangat dan motivasi belajar siswa di kelas. Sebagaimana Maulidah, 2017 yang menemukan terdapat hubungan yang signifikan antara kemampuan guru mengelola kelas dengan motivasi belajar siswa (Maulida, 2017). Sehingga pengelolaan kelas dalam kegiatan pembelajaran sangat penting dan merupakan hal yang mutlak.

Berdasarkan alasan tersebut, pengelolaan kelas dalam kegiatan pembelajaran sangat penting dan menjadi hal yang mutlak. Sehingga kajian tentang Strategi Pengelolaan Kelas dalam Menciptakan Suasana Belajar yang Kondusif di SD/MI sangat diperlukan.

\section{Metode}

Pendekatan yang digunakan dalam penelitian ini adalah pendekatan kualitatif, dengan maksud peneliti dapat mendeskripsikan secara jelas dan terperinci, serta mendapatkan data yang mendalam dari fokus penelitian tentang strategi pengelolaan kelas dalam menciptakan suasana belajar yang kondusif di Madrasah Ibtidaiyah Khadijah Malang. Dengan jenis penelitian studi kasus (Case Study). Teknik pengumpulan data yang digunakan adalah observasi, wawancara, dan dokumentasi, Sedangkan tehnik analisis data menggunakan model interaktif Miles dan Huberman, meliputi tiga tahap, yaitu: kondesasi data, penyajian data dan penarikan kesimpulan. Sedangkan sumber data diperoleh dari seluruh guru yang mengajar di kelas I sampai dengan kelas VI MI Khadijah, siswa dan semua pihak yang mendukung untuk mengumpulkan data-data penelitian tentang strategi 
Abd. Gafur, Fita Mustafida

pengelolaan kelas di MI Khadijah. Untuk mengecek keabsahan data digunakan tehnik triangulasi sumber dan metode pengumpulan data.

\section{Pembahasan dan Hasil Penelitian}

Berdasarkan hasil analisis data observasi, wawancara dan dokumentasi terkait dengan keterampilan mengelola kelas guru di MI Khadijah. Ditemukan beberapa strategi pengelolaan kelas yang dikembangkan guru MI Khadijah. Antara lain:

\section{Strategi Pengelolaan Fisik}

Dalam upaya pengelolaan fisik, strategi yang digunakan guru MI Khadijah adalah dengan mengatur ruangan seindah dan senyaman mungkin. Mulai dari warna dinding, penataan ruang kelas yang meliputi penataan tempat duduk, rak buku, pencahayaan, kebersihan kelas, memajang hasil karya siswa yang diganti setiap minggu, dan memajang kata-kata bijak yang dapat membangkitkan memotivasi belajar siswa.

Selain itu, strategi pengelolaan fisik juga dilakukan melalui pengaturan tempat duduk sering diubah sesuai dengan kebutuhan kegiatan belajar mengajar. Perubahan tempat duduk siswa dilakukan minimal 1 bulan sekali. Yang bertujuan supaya siswa mendapat suasana baru dan tidak bosan. Masing-masing kelas di MI Khadijah juga memiliki rak buku yang berisikan berbagai buku bacaan yang difungsikan sebagai perpustakaan di dalam kelas, sehingga ketika siswa membutuhkan buku dengan segera dapat membaca di kelas tanpa harus pergi ke perpustakaan. Fasilitas tersebut selain bermanfaat untuk menambah pengetahuan siswa, juga dapat meminimalisir kemunginan siswa yang sudah selesai mengerjakan tugas atau soal ujian ramai sembari menunggu waktu berakhirnya jam pelajaran. Untuk menjaga kebersihan dan kerapian kelas guru MI Khadijah juga membentuk piket kelas. Serta ada beberapa guru yang mengkaitkan saksi/hukuman siswa dengan kebersihan misalnya menyapu kelas. Dengan tindakan tersebut kelas akan selalu terjaga kebersihannya, dan siapapun yang ada di dalamnya akan merasa nyaman.

Melihat realitas tersebut, telah menunjukkan bahwa guru MI Khadijah memiliki ketrampilan mengelola kelas yang baik. Sebagaimana dikatakan (Harjali, 2016) penataan lingkungan kelas yang mempertimbangkan aspek kenyamanan dan keindahan merupakan syarat penting bagi terciptanya lingkungan belajar yang kondusif. Pengembangan strategi pengelolaan fisik tersebut sejalan dengan pendapat (Kozulin, 1998) bahwa guru bisa mencegah munculnya beberapa gangguan dalam kelas dengan menjaga kondisi fisik dan tata ruang kelas. 


\section{Pengelolaan Siswa}

Terkait upaya dalam mengatasi masalah-masalah pengelolaan yang berhubungan dengan prilaku siswa guru MI Khadijah mempunyai cara yang berbeda-beda, diantaranya dengan melakukan komitmen di awal ajaran baru baik secara tertulis maupun tidak tertulis, mengkomunikasikan dengan orang tua murid, pendekatan personal, serta memberi selingan dengan lagu-lagu/tepuk-tepuk, dan berbagai gerakan yang menyenangkan supaya siswa tidak bosan.

Selanjutnya untuk mengatasi masalah pengelolaan kelas yang terjadi di MI Khadijah guru melihat dulu jenis masalahnya, baru kemudian menentukan tindakan, seperti memberi teguran jika siswa melanggar untuk kali pertama, dan apabila siswa mengulanginya barulah diberikan sanksi/hukuman, dan apabila diperlukan juga melibatkan teman sejawat dan orang tua untuk menyelesaikannya. Strategi ini dalam istilah pengelolaan kelas merupakan bentuk dari pendekatan behaviour modification ( memadukan antara hukuman dengan pendekatan sosio emosional serta komunikasi yang baik dengan wali murid).

Berdasarkan analisis di atas, secara garis besar strategi pengelolan siswa dapat dilakukan dengan cara sebagai berikut:

\section{a. Melakukan tindakan preventif (pencegahan) sebagai metode untuk antisipasi atau mencegah munculnya masalah.}

Menurut Nurhadi, tindakan pencegahan dalam pengelolaan kelas adalah usaha guru melakukan insiatif untuk menciptakan suatu kondisi yang menguntungkan bagi proses belajar mengajar, baik berupa tindakan, contoh atau pemberian informasi yang dapat diberikan kepada siswa sehingga akan berkembang motivasi yang tinggi, atau agar motivasi yang sudah baik itu tidak dinodai oleh tindakan siswa yang menyimpang sehingga mengganggu proses belajar mengajar di kelas (Mulyani Sumantri dan Johar Permana., 2001). Adapun tindakan preventif dapat dilakukan guru dengan cara sebagai berikut:

1) Memperhatikan lingkungan belajar mulai dari ruangan kelas (penataan tempat duduk, rak buku, perpustakaan kelas, pencahayaan, dan kebersihan kelas, dan lainnya.

2) Membuat komitmen di awal tentang aturan-aturan atau tata tertib yang disepakati bersama di awal pembelajaran. Dengan adanya kesepakatan yang dibangun bersama-sama tersebut menunjukkan bahwa guru telah menggunakan pendekatan keseimbangan peran sebagaimana yang dikemukakan Pupuh, bahwa dalam mengelola kelas guru juga dapat menggunakan pendekatan keseimbangan peran yaitu dengan memberi seperangkat aturan yang disepakati guru dan murid. Isi aturan berkaitan 
dengan apa yang harus dan apa yang tidak boleh dikerjakan guru dalam mereaksi semua masalah atau situasi yang terjadi di kelas dan aturan yang boleh atau tidak boleh dilakukan murid selama belajar.(Fathurrohman Pupuh, Sutikno, 2007). Berdasarkan data tersebut juga menunjukkan bahwa guru juga memperhatikan perkembangan psikologis peserta didiknya. Hal tersebut dapat dilihat dari alasan pembentukan peraturan kelas yang dilakukan bersama-sama guru dan murid, yaitu untuk menciptakan hubungan yang baik dengan siswa. Sehingga siswa tidak merasa takut kepada guru dan tidak tertekan dengan aturan yang dibuat. Karena apabila hal itu terjadi siswa dapat berpura-pura patuh pada guru yang membuat aturan saja, apabila guru lain yang mengajar akan berprilaku sebaliknya. Hal tersebut didasarkan pada pendapatnya Mulyasa bahwa emosi primer manusia adalah mencari, perasaan takut, dan kemarahan (Mulyasa, 2013)

3) Tetap stabil dan proporsional dalam menghadapi siswa. Sikap ini merupakan wujud dari peningkatan kesadaran diri sebagai guru terhadap kegiatan profesinya. Sikap guru yang demokratis, menunjukan kepribadian yang stabil, harmonis serta berwibawa. Sehingga dengan sikap tersebut anak akan merasa diperhatikan dan nyaman berada di kelas.

4) Memberi teladan yang baik kepada siswa seperti selalu datang tepat waktu serta menjunjung tinggi peraturan yang sudah disepakati

5) Meskipun hukuman dalam pengelolaan kelas masih bersifat kontroversial (dipertentangkan), namun hukuman diperbolehkan, tetapi hendaknya hukuman disesuaikan dengan perkembangan anak-anak dan dilakukan secara adil, sehingga tidak menimbulkan kebencian anak pada guru yang berakibat timbulnya masalah baru (Harlock, 2005). Lebih lanjut (Harlock, 2005) memperbolehkan hukuman jika dapat mendorong anak untuk menyesuaikan diri dengan harapan sosial berikutnya yang lebih baik.

6) Menjalin komunikasi dengan orang tua siswa

Dalam hal ini komunikasi dilakukan secara langsung melalui pertemuan guru dengan orang tua setiap triwulan terkait masalah yang dihadapi di sekolah dan bentk kerjasama dalam mendidik siswa. Serta komunikasi tertulis melalui buku catatan siswa yang berisi seluruh kegiatan di sekolah dan tugas-tagas belajar yang harus ditandatangani oleh guru dan orang tua setiap harinya. Sehingga dengan buku catatan tersebut guru dapat melaporkan berbagai kegiatan pada orang tua dan memudahkan bagi kedua belah pihak untuk melakukan controling terhadap aktivitas pembelajaran anak. 


\section{b. Melakukan tindakan kuratif jika muncul masalah pengelolaan kelas}

Tindakan kuratif dilakukan ketika guru telah melakukan tindakan kuratif namun di tengah-tengah kegiatan belajar muncul masalah. Berbeda dengan tindakan kuratif yang bertujuan untuk mengantisipasi muncul berbagai masalah pengelolaan kelas, maka pada strategi ini pengelolaan kelas lebih ditujukan untuk bagaimana mengatasi masalah pengelolaan kelas yang muncul. Diantara tindakan kuratif yang dapat dilakukan dalam mengelola kelas adalah:

1) Memberikan teguran, ancaman

Teguran efektif digunakan untuk menghentikan tingkah-laku siswa yang ingin mendapatkan perhatian orang lain (attention getting behaviors). Asumsinya, jika prilaku dibiarkan tindakan tersebut akan memicu pada pengalihan perhatian teman-teman yang lain dan menimbulkan masalah baru. Sementara ancaman bermanfaat sebagai kontrol dalam menerapkan pendekatan hukuman. Tetapi, ancaman ini juga kurang baik jika sering dilakukan, karena dari ancaman yang tidak ada tindakan menyebabkan siswa menyepelekan ancaman guru dan menyebabkan sikap yang tidak baik.

2) Menggunakan gerakan tubuh (gesture) yang dipahami siswa.

Berdasarkan teori pengelolaan kelas, strategi megubah gerakan angota badan dan ekspresi mimik wajah bagus dilakukan dalam pengelolaan kelas, tetapi lebih ditekankan pada pemberian penguatan yang positif terhadap prilaku baik siswa.(Ahmad Rohani, 1991) Seperti memberi isyarat persetujuan, senyuman, anggukan, menggangkat jempol tangan, membesarkan hati dan berbagai penguatan non verbal seperti merubah mimik wajah, gerakan badan (gesture), mendekati siswa, dan kegiatan yang menyenangkan (Arikunto, 1992) Tetapi kalau sikap ini dilakukan untuk mengatasi masalah siswa yang ramai menjadikan kesan gurunya galak, jahat, dan menakutkan. Sehingga siswa menghentikan tindakannya atas dasar rasa takut pada guru bukan untuk perubahan yang lebih baik.

3) Menerapkan pendekatan personal

Pendekatan personal perlu dilakukan guru supaya ada kedekatan antara guru dengan siswa. Pendekatan ini efektif dilakukan dalam mebangun hubungan emosional yang baik antara guru dengan siswa. Pendekatan personal yaitu dengan mendekati siswa dan menanyakan kenapa melakukan tindakan tersebut, dapat juga diterapkan untuk menghadapi jika ditemukan siswa yang minder di kelas, kurang percaya diri, supaya dapat membesarkan hati siswa, menanamkan rasa percara diri secara perlahan dan berkesinambungan. Strategi ini digunakan jika ada siswa yang menunjukkan ketidakmampuan 
(helpness) yang sama sekali menolak untuk mencoba melakukan apapun karena yakin bahwa hanya kegagalanlah yang menjadi bagiannya. Dalam istilah pengelolaan kelas dinamakan sebagai (Passive Behaviour). Untuk menangani siswa seperti ini guru dapat melakukannya dengan mendekati dan mengontrol pekerjaannya sambil memberikan pertolongan kesulitan siswa. Serta memberikan dorongan secara terus menerus sampai rasa percaya dirinya tumbuh (Mustafida, Abd. Gafur, 2019).

\section{Simpulan}

Berdasarkan analisis pembahasan di atas maka dapat disimpulkan bahwa dalam kegiatan pembelajaran guru perlu memiliki keterampilan mengelola kelas. Hal ini dilakukan guna menciptakan suasana pembelajaran yang kondusif dan mendukung terhadap pencapaian tujuan pembelajaran. Adapun dalam mengatasi masalah-masalah pengelolaan kelas guru dapat menggunakan dua pendekatan; preventif untuk menciptakan dan mengantisipasi munculnya masalah pengelolaan kelas, serta pendekatan kuratif sebagai langkah penanggulangan bila muncul masalah-masalah dalam mempertahankan dan mengembalikan kondisi pembelajaran.

Strategi pengelolaan kelas yang dapat dilakukan guru diantaranya; membentuk lingkungan pembelajaran yang kondusif dan menyenangkan, membuat komitmen dengan peserta didik yang dibangun bersama, serta kepiawaian guru dalam melayani siswa dengan bersikap adil dan proporsional dengan pendekatan yang menghargai keragaman siswa. Selain itu guru juga perlu membangun komunikasi dengan orang tua untuk mencegah munculnya masalah pengelolaan kelas. Namun demikian ketika masalah pengelolaan kelas muncul guru dapat menanggulangi masalah pengelolaan kelas dengan menerpkan beberapa pendekatan seperti punisment reward, emosional, dan personal disesuaikan dengan situasi dan kondisi munculnya maslah di kelas.

\section{Daftar Rujukan}

Ahmad Rohani, A. A. (1991). Pengelolaan Pengajaran.

Arends, R. I. (2008). Learning to Teach (seventh edition) (New york: McGraw Hill Companies) (p. 287). Pustaka Pelajar,.

Arikunto, S. (1992). Pengelolaan Kelas dan Siswa (3rd ed.). Jakarta: CV. Rajawali.

De Porter, Bobby, trj. A. N. (2010). Quantum Teaching (Orchestrating Student Sucses). Terjemah Quantum Teaching (mempraktekkan quantum learning di 
Abd. Gafur, Fita Mustafida

ruang-ruang kelas). Bandung: Kaifa.

Fathurrohman, Pupuh Sutikno, M. S. (2007). Strategi Belajar Mengajar Melalui Penanaman Konsep Umum dan Konsep Islam. Bandung: PT. Refika Aditama.

Fita Mustafida, A. G. (2019). Strategi Pengelolaan Kelas Multikultural. (Abdul Halim, Ed.). Malang: UIN Malang Press.

Harjali. (2016). Strategi Guru dalam Membangun Lingkungan Belajar yang Kondusif: Studi Fenomenologi pada Kelas-kelas Sekolah Menengah Pertama di Ponorogo. JURNAL PENDIDIKAN DAN PEMBELAJARAN, 23(1).

Harlock, E. (2005). Developmental Psycologi (A life-Span Approch), fifth edition: Psikologi Perkembangan (Suatu Pendekatan Sepanjang Rentang kehidupan). (.[ed. Ridwan Max Sijabat, Ed.). Jakarta: Erlangga.

Imron, A. dkk. (2003). Manajemen Pendidikan. Malang: Universitas Negeri Malang.

Kozulin, A. (1998). Psychological Tools: A Socio-Cultural Approach to Education. London: Harvard University Press.

Maulida. (2017). Hubungan Kemampuan Guru Mengelola Kelas dengan Motivasi Belajar Siswa di SMK Kabupaten Tangerang. Universitas Pendidikan Indonesia.

Mulyani Sumantri dan Johar Permana. (2001). Strategi Belajar Mengajar. Bandung: CV. Maulana.

Mulyasa, E. (2013). Pengembangan dan Implementasi Kurikulum 2013. Bandung: PT Remaja Rosdakarya.

Nawawi, H. (1982). Organisasi Sekolah dan Pengelolaan Kelas sebagai Lembaga Pendidikan. Jakarta: Gunung Agung.

Reynolds, D. M. dan D. (2008). EffectiveTeaching (Evidence and Practice). London: Sage Publication.

Setyosari, P. (2009). Pembelajaran Kolaborasi, Landasan untuk Mengembangkan Ketrampilan Sosial, Rasa Saling Menghargai dan Tanggung Jawab. Malang. 